\title{
Assessing the iron chelation capacity of goat casein digest isolates
}

\author{
A. Smialowska, L. Matia-Merino, and A. J. Carr ${ }^{1}$
}

Massey Institute of Food Science and Technology, School of Food and Nutrition, Massey University, Palmerston North, 4442, New Zealand

\begin{abstract}
We isolated goat phosphopeptides via calcium and ethanol precipitation from a caseinate digest and investigated their feasibility as an iron-fortification ingredient in nutritional foods. Goat tryptic-digested phosphopeptides could bind $54.37 \pm 0.50 \mathrm{mg}$ of $\mathrm{Fe} / \mathrm{g}$ of protein compared with goat milk, which could bind 3.83 $\pm 0.01 \mathrm{mg}$ of $\mathrm{Fe} / \mathrm{g}$ of protein, indicating that isolation did increase iron binding. However, the $>13$-fold increase in iron binding was only partly explained by the increased concentration of phosphoserine-rich residues in the isolated fraction: we observed a $77 \%$ increase in serine residue content and a 5.9-fold increase in phosphorus in the goat peptide isolate compared with the starting caseinate material. We investigated the effect of potential industrial processing conditions (including heating, cooling, holding time, and processing order) on iron binding by the tryptic-digested phosphopeptides. In addition, we tested the effect of ionic strength and the addition of peptides to a milk system to understand how food formulations could affect iron binding. Key words: iron, chelation, goat casein, peptides
\end{abstract}

\section{INTRODUCTION}

Anemia is a worldwide issue: an estimated 2 billion people have low iron, and this has many repercussions, including decreased energy levels, fatigue, and cold intolerance (Miller, 2013). In children, low iron can affect neurological development, immunity, and growth (Kibangou et al., 2005). Although iron is found in a variety of foods, cohorts such as the elderly (Busti et al., 2014), women of childbearing age (Patterson et al., 2001), and infants unable to breastfeed may find it difficult to achieve adequate iron intake. As well, iron fortification in food can negatively affect product quality. For example, one problem in applications containing oil is that soluble iron forms can act as pro-oxidants, leading fats to become rancid more quickly. This results

Received September 30, 2016.

Accepted December 21, 2016.

${ }^{1}$ Corresponding author: A.J.Carr@massey.ac.nz in a loss of nutrient value and consumer acceptance because of negative effects on organoleptic quality and gastrointestinal discomfort in people with compromised health or sensitive digestive systems, such as infants (McClements and Decker, 2000).

Phosphopeptides from $\alpha_{\mathrm{S}^{-}}, \alpha_{\mathrm{S}^{-}}$, and $\beta$-caseins contain highly polar acidic sequences of 3 phosphoseryl groups followed by 2 glutamic acid residues (SpSpSpEE; Bouhallab and Bouglé, 2004; Miquel et al., 2006) that enable the peptides to bind cationic minerals. Phosphoserine groups bind iron via coordination and ionic linkages (Baumy and Brule, 1988; Pérès et al., 1999), and calcium binds via ionic bonding only (Baumy and Brule, 1988); both calcium and iron can also bind to the carboxylic groups on the caseins, but with less affinity (Baumy and Brule, 1988; Swaisgood, 2003). Phosphopeptides have been shown to be stable and soluble over a range of physicochemical conditions, such as changes in pH (Ait-Oukhatar et al., 2000).

In terms of nutritional significance, iron-fortified phosphopeptides increased iron absorption in rats compared with iron gluconate (Pérès et al., 1999). Similarly, Ait-Oukhatar et al. (1999) evaluated the ability of iron-deficient rats to restore hemoglobin levels using a low-molecular-weight phosphopeptide compared with $\mathrm{FeSO}_{4}$ and intact $\beta-\mathrm{CN}$. The $\beta-\mathrm{CN}(1-25)$ peptide fortified with iron improved iron tissue storage and hemoglobin levels compared with $\mathrm{FeSO}_{4}$. Whole casein bound to iron also showed an improvement, but not to the same extent on an equal-protein diet. These findings were supported by Bouhallab et al., (2002), who found that iron absorption was greater using the $\beta-\mathrm{CN}(1-25)$ peptide than with a whole digest of $\beta-\mathrm{CN}$ and a mixture of casein phosphopeptides.

Methods for isolating phosphopeptides that are highly saturated with calcium to remineralize enamel have been developed (Reynolds et al., 1994; Adamson and Reynolds, 1995; Adamson and Reynolds, 1996) and used by different authors (McDonagh and FitzGerald, 1998; Corsetti et al., 2003; Kim et al., 2007). Corsetti et al. (2003) studied the yield and calcium-binding properties of phosphopeptides derived from different species and found that goat caseinate produced the highest yield but had a lower capacity to bind calcium than 
casein phosphopeptides derived from bovine caseinate. Iron-bound phosphopeptides from cow caseinate have been prepared for absorption studies. Bouhallab et al. (2002), Chaud et al. (2002), and Kibangou et al. (2005) produced iron-bound phosphopeptides by digesting caseinate, adding iron, and then filtering the solution or isolating the complex by dialysis (Ait-Oukhatar et al., 1999). The purpose of our study was to assess how goat caseinate performed as a precursor for phosphopeptides that could bind iron under simulated industrial processing conditions. We carried out the same process using cow caseinate as a reference during the isolation stage, because of the greater depth of information in the literature.

\section{MATERIALS AND METHODS}

\section{Materials}

Goat and cow caseinate were prepared by isoelectric precipitation of reconstituted goat (predominantly Saanen) or cow milk powder obtained from Dairy Goat Co-operative (Hamilton, New Zealand), and Fonterra Co-operative (purchased from Milligans Food Group Ltd., Oamaru, New Zealand), respectively. Briefly, the skim milk powders were hydrated to $10 \%$ (wt/wt) and acidified to $\mathrm{pH} 4.6$ for cow and 4.2 for goat milk at $15^{\circ} \mathrm{C}$. The solutions were warmed to $30^{\circ} \mathrm{C}$ and the precipitate collected by centrifugation. The precipitates were caseinated by addition of sodium hydroxide to $\mathrm{pH} 6.7$ and freeze-dried. We obtained ammonium bicarbonate, ammonium molybdate, disodium tetraborate, and sodium sulfite from $\mathrm{BDH}$ Chemicals (Poole, UK); hydrochloric acid, sodium hydroxide, 2-propanol, acetonitrile, trifluoroacetic acid, and ferrous sulfate from Fisher Scientific (Leicestershire, UK); hydrogen peroxide, disodium EDTA, and sodium chloride from LabServ (Biolab, Australia); o-phthaldialdehyde (OPA), dithiothreitol, serine, ferrozine, and neocuprione from Sigma (St. Louis, MO); Eriochromeback $\mathrm{T}$ indicator from Riedel-de Haën (Seelze, Germany); and trypsin (Pancreatic Trypsin Novo 6.0S) from Novozymes (Bagsvaerd, Denmark). All water was MilliQ grade, and all other chemicals were analytical grade. The spectrophotometer used throughout was Pharmica UV/visible Ultrospec II (LKB, Biochem, Cambridge, $\mathrm{UK})$.

\section{Hydrolysis}

The goat and cow caseinates were hydrolyzed using the methods of Reynolds et al. (1994), Adamson and
Reynolds (1996), and Strader et al. (2006) with modifications. Sodium caseinates $(35 \mathrm{mg} / \mathrm{mL})$ were dissolved in $50 \mathrm{~m} M$ ammonium bicarbonate solution, $\mathrm{pH}$ 8.0. Commercial grade trypsin hydrated in $1 \mathrm{~m} M \mathrm{HCl}$ at $4 \mathrm{mg} / \mathrm{mL}$ was added to the solution at an enzyme to protein ratio of 1:200 with rapid stirring. Digestion was maintained at $37^{\circ} \mathrm{C}$ overnight, and the reaction stopped by heating the solutions to $75^{\circ} \mathrm{C}$ for $10 \mathrm{~min}$. The $\mathrm{pH}$ was lowered to $\mathrm{pH} 4.6 \pm 0.1$ and the solutions centrifuged at $12,000 \times g$ for $10 \mathrm{~min}$ (Sorvall RC $6+$, ThermoFisher Scientific, Waltham, MA) to remove undigested material. The serum $\mathrm{pH}$ was increased to $\mathrm{pH} 6.74 \pm 0.03$ and a $10 \%$ calcium chloride solution was added slowly at room temperature to a final concentration of $100 \mathrm{mM}$. The solution was incubated at room temperature for $1 \mathrm{~h}, 95 \%$ ethanol was added to a final $50 \%$ ( $\mathrm{vol} / \mathrm{vol})$ concentration by slow addition. The solution was centrifuged at $12,000 \times g$ for $15 \mathrm{~min}$ (Thermo Sorvall RC 6+, rotor type: F21S-8x50, ThermoFisher Scientific) and the pellet was collected and freeze-dried. The hydrolysis was carried out in triplicate for each species.

\section{Calcium Ion Exchange of Phosphopeptides}

A weight of $50 \mathrm{mg}$ of peptide solids was dissolved in 5 $\mathrm{mL}$ of deionized water. Amberlite IRC-50 resin (Rohm \& Haas Company, Philadelphia, PA) was prepared by washing the resin in $1 \mathrm{M} \mathrm{NaOH}$ for $1 \mathrm{~h}$ to charge it to the sodium form and then rinsing it with water until the $\mathrm{pH}$ was close to $\mathrm{pH} 7.0$ (Mittal et al., 2015). Then, $0.1 \mathrm{~mL}$ of wet resin was added to the peptide solution, mixed gently, and incubated overnight at $4^{\circ} \mathrm{C}$; finally, the solutions were decanted from the resin.

\section{Degree of Hydrolysis}

We evaluated the degree of hydrolysis (DH) according to Nielsen et al. (2001). The OPA reagent was prepared by mixing $1.14 \mathrm{~g}$ of disodium-tetraborate decahydrate and $30 \mathrm{mg}$ of SDS in $22.5 \mathrm{~mL}$ of water until fully dissolved. The OPA $(24 \mathrm{mg})$ was dissolved in $0.6 \mathrm{~mL}$ of ethanol and followed by addition of $26.4 \mathrm{mg}$ of dithiothreitol, and the solution was made up to $30 \mathrm{~mL}$. Samples were diluted to $0.8 \mathrm{mg} / \mathrm{mL}$ in water; $0.75 \mathrm{~mL}$ of $\mathrm{OPA}$ reagent was added to $100 \mu \mathrm{L}$ of sample, mixed for $5 \mathrm{~s}$, and measured at $340 \mathrm{~nm}$ exactly 2 min after addition. The standard used was $0.01 \%$ (wt/vol) serine solution with a milli-equivalence of $0.9516 \mathrm{mEq} / \mathrm{L}$. The degree of hydrolysis was determined as a percentage of cleaved peptide bonds: 


$$
\begin{aligned}
\text { Serine- } \mathrm{NH}_{2} & =\frac{\mathrm{OD}_{\text {sample }}-\mathrm{OD}_{\text {blank }}}{\mathrm{OD}_{\text {standard }}-\mathrm{OD}_{\text {blank }}} \times 0.9516 \mathrm{mEq} / \mathrm{L} \\
& \times 0.1 \times \frac{100}{\mathrm{X}} \times \mathrm{P}
\end{aligned}
$$

where serine- $\mathrm{NH}_{2}$ was the equivalents of serine- $\mathrm{N}$ per gram of protein, OD is optical density, $\mathrm{X}$ was the amount (g) of the sample, $\mathrm{P}$ was the protein (\%) in the sample, and 0.1 was the sample volume in $\mathrm{L}$.

$$
\begin{gathered}
\mathrm{H}=\frac{\text { serine- } \mathrm{NH}_{2}-\beta}{(\alpha \mathrm{mEq} / \mathrm{g} \text { of protein })}, \\
\mathrm{DH}(\%)=\frac{\mathrm{H}}{\mathrm{h}_{\mathrm{tot}}} \times 100 \%,
\end{gathered}
$$

where $\alpha, \beta$, and $h_{\text {tot }}$ were defined by Nielsen et al. (2001) as 1.039, 0.383, and 8.2 for casein, respectively, and $\mathrm{H}$ was the number of hydrolyzed bonds. After $18 \mathrm{~h}$ of digestion, the $\mathrm{DH}$ was $27.1 \pm 0.6 \%$ for cow and 26.3 $\pm 0.8 \%$ for goat caseinate $(P>0.05)$.

\section{Phosphorus Content}

The phosphorus content was determined using the method of Bartlett (1959). Samples were prepared by dissolving peptide powders in water to $0.7 \mathrm{mg} / \mathrm{mL}$, and $2 \mathrm{~mL}$ of the solution was pipetted into boiling tubes. Then, $0.5 \mathrm{~mL}$ of $5 \mathrm{M}$ sulfuric acid was added to the boiling tubes and heated at $155^{\circ} \mathrm{C}$ for $3 \mathrm{~h}$. Hydrogen peroxide was added $(0.1 \mathrm{~mL}$ or until the solution was close to clear) and the solution was further heated for $90 \mathrm{~min}$. Ammonium molybdate $(0.22 \%, 4.6 \mathrm{~mL})$ was added, followed by addition of $0.2 \mathrm{~mL}$ of Fiske reducer [0.0625 g of 1-amino-2-napthol-sulfonic acid and 0.125 $\mathrm{g}$ of sodium sulfite in $25 \mathrm{~mL}$ of $15 \%$ sodium bisulfite $(3.75 \mathrm{~g})$; filtered]. The solution was heated at $100^{\circ} \mathrm{C}$ for $7 \mathrm{~min}$ and then read at $830 \mathrm{~nm}$.

\section{Calcium Content}

Calcium was determined using calcium-EDTA titration with Eriochromeblack T indicator. Borate buffer was prepared by dissolving $3.332 \mathrm{~g}$ of sodium tetraborate decahydrate in $80 \mathrm{~mL}$ of water. Sodium hydroxide $(0.54 \mathrm{~g})$ and sodium sulfide $(0.4165 \mathrm{~g})$ were dissolved and added to the borate solution and made up to 100 $\mathrm{mL}$. The indicator solution was made by dissolving 0.1 $\mathrm{g}$ of Eriochromeblack $\mathrm{T}$ powder in $3 \mathrm{~mL}$ of water and $0.1 \mathrm{~mL}$ of $1 \mathrm{~N}$ sodium carbonate and made up to $10 \mathrm{~mL}$ with 2-propanol. A $1 \mathrm{~m} M$ or $5 \mathrm{~m} M$ EDTA titrant was prepared by with disodium EDTA dehydrate. For a 25$\mathrm{mL}$ sample, $0.5 \mathrm{~mL}$ of borate buffer was added followed by addition of $0.025 \mathrm{~mL}$ of indicator and titrating until a light blue endpoint was achieved.

\section{Protein Content of Peptide Isolates}

The protein concentration of the ion-exchanged solutions was determined using the Lowry method with the Ohnishi and Barr modification using the total protein kit by Sigma (TP0200) according to the manufacturer's directions (http://www.sigmaaldrich.com/content/ dam/sigma-aldrich/docs/Sigma/Bulletin/tp0200bul. pdf). Samples were diluted in $0.85 \%$ sodium chloride solution in the range of 150 to $1,000 \mu \mathrm{g} / \mathrm{mL}$, and 0.2 $\mathrm{mL}$ of sample was combined with $2.2 \mathrm{~mL}$ of Biuret reagent and incubated for $10 \mathrm{~min}$ followed by addition of $0.1 \mathrm{~mL}$ of Folin-Ciocalteau reagent and incubated for $30 \mathrm{~min}$. The samples were measured against a standard curve prepared from a stock protein standard provided. The absorbance was measured at $550 \mathrm{~nm}$.

\section{Amino Acid Profile}

The Massey University Nutrition Laboratory (Palmerston North, New Zealand) performed the amino acid analysis. The methodology used was standard AAA hydrochloric acid hydrolysis, followed by reversedphase HPLC separation using AccQ Tag derivatization (AOAC International, 2012; method 994.12).

\section{Reversed-Phase HPLC}

The RP-HPLC was performed with a 1200 Series apparatus from Aligent Technologies (Santa Clara, CA) equipped with an G1311A Quaternary pump and 1200 Series sample injector and UV detector. The chromatographic software used was EZChrom (Agilent Technologies Inc., Santa Clara, CA). The apparatus was equipped with a RP column, Prevail C18 (150 $\times 4.6 \mathrm{~mm}$ i.d., 5 - $\mu \mathrm{m}$ pore size; Chromservis, Prague, Czech Republic). The samples were prepared by dissolving in $90 \% \mathrm{H}_{2} \mathrm{O}$ and $10 \%$ acetonitrile to $2 \mathrm{mg} /$ $\mathrm{mL}$. The samples were centrifuged at 13,300 $\times g$ for 10 min. Two buffers: A containing 95\% MilliQ water, $5 \%$ acetonitrile, and $0.1 \%$ trifluoroacetic acid (TFA) and B containing 95\% acetonitrile, 5\% MilliQ water, and $0.08 \%$ TFA were used for elution.

A linear gradient was performed with $50 \mathrm{~mL} / \mathrm{L}$ buffer $\mathrm{B}$ in 5 min followed by 50 to $600 \mathrm{~mL} / \mathrm{L}$ buffer B within $120 \mathrm{~min}$, followed by 600 to $900 \mathrm{~mL} / \mathrm{L}$ within $121 \mathrm{~min}$. 
At a flow rate of $1 \mathrm{~mL} / \mathrm{min}$, a $5-\mu \mathrm{L}$ sample was injected onto the column, maintained at $25^{\circ} \mathrm{C}$, and the absorbance was measured at 214 and $280 \mathrm{~nm}$.

\section{Iron Chelation}

Samples were diluted to $0.2 \mathrm{mg} / \mathrm{mL}$ in a modified simulated milk ultrafiltrate buffer $(20 \mathrm{~m} M$ imidazole, $30 \mathrm{~m} M \mathrm{NaCl}, \mathrm{pH} 6.7$ ) to maintain a constant $\mathrm{pH}$. A $0.93-\mathrm{mL}$ aliquot was mixed with $0.025 \mathrm{~mL}$ of $1 \mathrm{mM}$ $\mathrm{FeSO}_{4}$ in $1 \mathrm{mM} \mathrm{HCl}$, and held for $3 \mathrm{~min}$. Variations of these conditions were adjusted as required, significant changes to the method are detailed below.

Effect of pH, Temperature, and Ionic Strength. The peptides were subjected to buffer conditions at various combinations of $\mathrm{pH}(\mathrm{pH} \mathrm{2.75}, 4.6$, and 6.7), ionic strength $(50 \mathrm{~m} M, 400 \mathrm{mM})$ and temperature $\left(4^{\circ} \mathrm{C}\right.$, $20^{\circ} \mathrm{C}, 37^{\circ} \mathrm{C}, 72^{\circ} \mathrm{C}$ ) to which ferrous sulfate was added.

Addition of Peptides to a Milk Model. Milk powder was reconstituted in water to $10 \%$ (wt/wt) solids at $20^{\circ} \mathrm{C}$ and mixed for $2 \mathrm{~h}$ before being chilled overnight at $4^{\circ} \mathrm{C}$. After overnight storage, the milk solutions were diluted to $0.2 \mathrm{mg} / \mathrm{mL}$ in imidazole buffer and peptides solubilized in buffer were added where the volumes were varied to produce different ratios of milk protein to peptide to achieve a final $0.2 \mathrm{mg} / \mathrm{mL}$ protein concentration. Iron binding was carried out at $20^{\circ} \mathrm{C}$ to limit the effects of temperature on oxidation; equal iron fortification of $28 \mu \mathrm{M}$ was used across all the samples. The order of addition of iron to the solution was varied to reflect the various process options that are possible and whether these process options affect iron binding by the peptides. Accordingly, ferrous sulfate was either added to the peptide solution and held for $3 \mathrm{~min}$ and then added to the milk solution or the peptide and milk solution were mixed then the iron was added to this.

Ferrozine $(6.09 \mathrm{mM}, 0.04 \mathrm{~mL})$ was added to stop the binding reaction; the mixture was held for $10 \mathrm{~min}$ to allow color development and then read at $562 \mathrm{~nm}$. There is potential for error as oxidized iron in the ferric form will not be detected and therefore could produce a false positive for bound iron. Due to the nature of the technique, it is difficult to assess how much iron is oxidized or bound other than doing a baseline calculation under identical conditions by using a blank.

We calculated the iron chelation and activity as follows (Abs = absorbance):

$$
\text { Fe chelation }=\frac{\mathrm{Abs}_{\text {blank }}-\mathrm{Abs}_{\text {sample }}}{A \mathrm{bs}_{\text {blank }}},
$$

Fe chelation activity $=\frac{\text { Fe chelation } \times \text { Fe added }(\mu M)}{\text { Protein }(\mathrm{mg} / \mathrm{mL})}$.

\section{Statistical Analysis}

Data were analyzed using a 2-sample $t$-test after checking for homogeneity of variances using F-test or ANOVA where appropriate. Analysis was carried out using R (Harrell et al., 2014; R Development Core Team, 2014).

\section{RESULTS AND DISCUSSION}

\section{Yield}

The yield of goat phosphopeptides from the original caseinate solution was $15.3 \pm 0.2 \%$ (wt/wt). By changing the enzyme system and processing conditions, the yield of casein phosphopeptides can vary greatly. Reynolds et al. (1994) reported a yield of $10.50 \pm 0.4 \%$ (wt/ wt) from a tryptic digest of cow caseinate at $\mathrm{pH} 3.5$. Adamson and Reynolds (1995), who also used trypsin, obtained a yield of $11.04 \pm 0.30 \%$ (wt/wt) at $\mathrm{pH} 4.6$, which increased to $13.85 \pm 0.48 \%$ (wt/wt) when the $\mathrm{pH}$ was raised to 8.0. The composition of the precipitate differed in terms of the phosphopeptide clusters; at higher $\mathrm{pH}$, the extraction loses specificity, whereby di- and monophosphopeptides can also be isolated (Reynolds et al., 1994). These authors also reported a slight increase in yield for a digest held at $\mathrm{pH} 4.6$ by substituting trypsin for alcalase because of its lower specificity (Adamson and Reynolds, 1996). Zhu and FitzGerald (2010) found that casein phosphopeptides were more stable against heating when the peptides were isolated at $\mathrm{pH}$ 7.0. McDonagh and FitzGerald (1998) used a wide range of enzymes, along with calcium and ethanol precipitation, and found a yield range of 3.4 to $16.0 \%$. Kim et al. (2007) found that the yield increased linearly from $\mathrm{pH} 3(5 \%)$ to $7(12 \%)$ and remained at $12 \%$ at $\mathrm{pH} 8.0$. It is likely that the peptides produced in our study may have contained a greater amount of di- and monophosphopeptides because of the higher precipitation $\mathrm{pH}$ and yield, but would be more stable during heating, an important property in the production of nutritional foods. Corsetti et al. (2003) reported a yield of casein phosphopeptides from goat caseinate of $1.86 \%$ (wt/wt). They used Lactobacillus helveticus PR4 on different species of sodium caseinate and found a yield of 0.6 to $1.86 \%$ (wt/wt). Their overall low yield compared with our study and other studies may have been because they used different culture and digestion conditions.

\section{Phosphorus Content}

The phosphorus content of the goat caseinate was $7.84 \pm 0.31 \mathrm{mg} / \mathrm{g}$ of solids, and of the cow caseinate was 
$7.03 \pm 0.8 \mathrm{mg} / \mathrm{g}$ of solids. These figures were similar to those reported in the literature: McMeekin and Polis (1949) and Díaz et al. (2003) reported values of 8.6 and $7 \mathrm{mg} / \mathrm{g}$ of cow casein, respectively. After digestion and calcium and ethanol precipitation, the phosphorus content of both the goat- and cow-derived phosphopeptides increased by more than $500 \%$ to $45.39 \pm 2.37 \mathrm{mg} / \mathrm{g}$ of solids and $40.08 \pm 1.57 \mathrm{mg} / \mathrm{g}$ of solids, respectively $(P$ $>0.05)$. On a percentage basis, the phosphorus content for both isolates, at $4.64 \%$ (goat) and $4.01 \%$ (cow), were similar to the content of approximately $5 \%$ for cow-casein-derived phosphopeptides obtained at $\mathrm{pH} 6.7$ reported by Kim et al. (2007).

\section{Amino Acid Profile}

Our results showed the relative change in composition of the amino acid residue content of cow and goat phosphopeptides compared with the starting material of the respective caseinates (Figure 1). Of the 16 amino acids measured in the goat peptide isolate (and 10 in the cow peptide digest), 9 decreased in concentration, indicating exclusion of the non-binding peptides. The predominant amino acid that increased was the serine residues, which increased by 77.7 and $72.3 \%$ for goatand cow-derived peptides, respectively. In addition to serine residues, glutamic acid, glycine, histidine, threonine, and isoleucine increased in goat-derived peptides and aspartic acid, glutamic acid, glycine, threonine, and isoleucine increased in cow-derived peptides. It is likely that the increase in these latter amino acids reflected their proximity to the serine residues on the primary amino acid sequence and thus the likelihood of coprecipitating as part of a serine-containing peptide. According to the sequence of caseins from UniProtKB (Apweiler et al., 2004), serine residues that make up the phosphoseryl clusters are surrounded by acidic residues such as glutamic acid (Reynolds et al., 1994). Comparing the theoretical amino acid profile and the expected cutting pattern of trypsin, we found that relative increases and decreases of the residues of the phosphoserine-containing peptides were similar to those observed in our study.

\section{Reversed-Phase HPLC}

Figure 2 shows the reversed-phase HPLC chromatograms for goat caseinate digests and the isolated peptides. We observed approximately 70 peaks in the original digest, similar to the number of theoretical peptides produced in a tryptic digest according to UniProtKB (Apweiler et al., 2004). After calcium and ethanol precipitation, the number of peaks reduced, indicating an isolation of peptides. The peptide isolate produced 1 in- tense peak, about 6 major peaks, and approximately 33 peaks in total. At $214 \mathrm{~nm}$, the peptide bonds were the absorbing species and were significantly more sensitive than at $280 \mathrm{~nm}$. Few peaks appeared at $280 \mathrm{~nm}$ (data not shown), as aromatic amino acids are detected, indicating that the peptides in the phosphopeptide fraction contained very few aromatic residues (Højrup, 2004; Mennella et al., 2010). This finding was supported by the amino acid analysis: phenylalanine and tyrosine decreased by $81 \%$ and $79 \%$, and histidine increased by $52 \%$ (tryptophan was not measured). Phosphopeptides were all eluted after $45 \mathrm{~min}$, whereas peptides from the full digest required up to $75 \mathrm{~min}$ before they were fully eluted. This observation indicates that the eluted phosphopeptides were small and more hydrophilic than those in the overall digest, as expected given the characteristics of phosphoserine.

In terms of the isolation mechanism, calcium binds to negatively charged phosphoserine residues or acidic residues via ionic bonding. At a low $\mathrm{pH}$, only multiply phosphorylated peptides extracted as acidic residues are protonated, and monophosphoserines do not have a strong negative charge (Reynolds et al., 1994). At $\mathrm{pH}$ 6.7 , the acidity at which the peptides were extracted in our study, selectivity would not be expected to be high, and monophosphopeptide groups would be extracted along with the phosphoserine clusters. For a

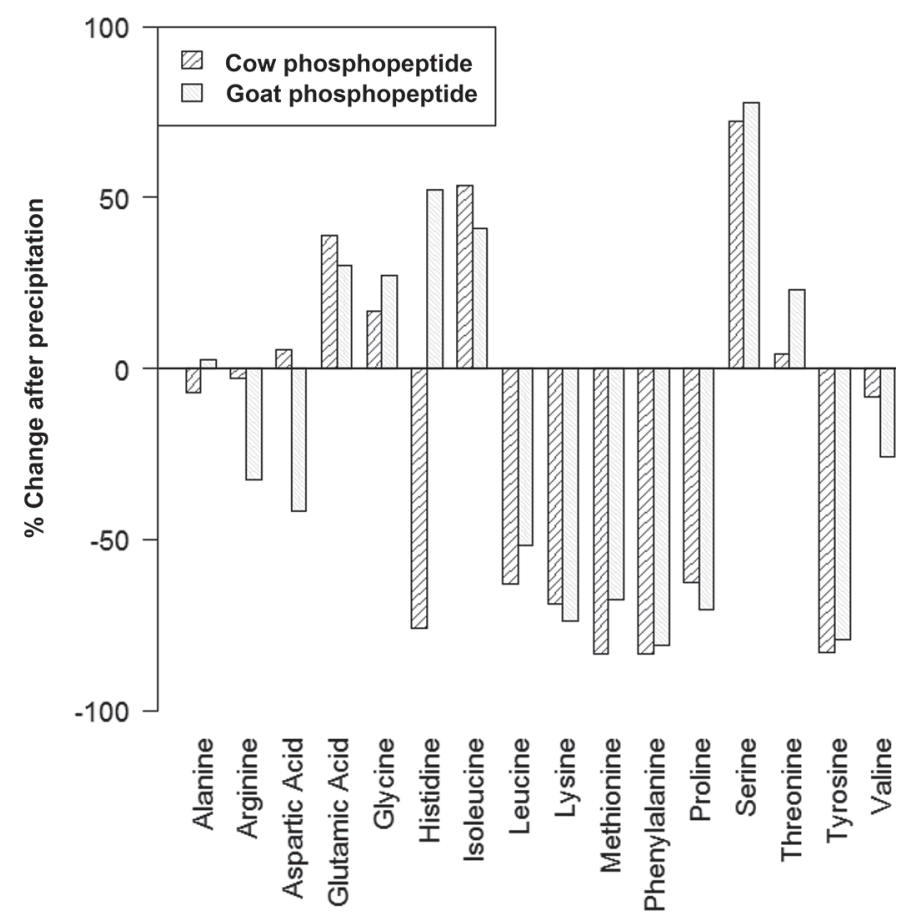

Figure 1. Percentage change in AA residues after calcium and ethanol precipitation compared with starting material for goat and cow caseinate. 


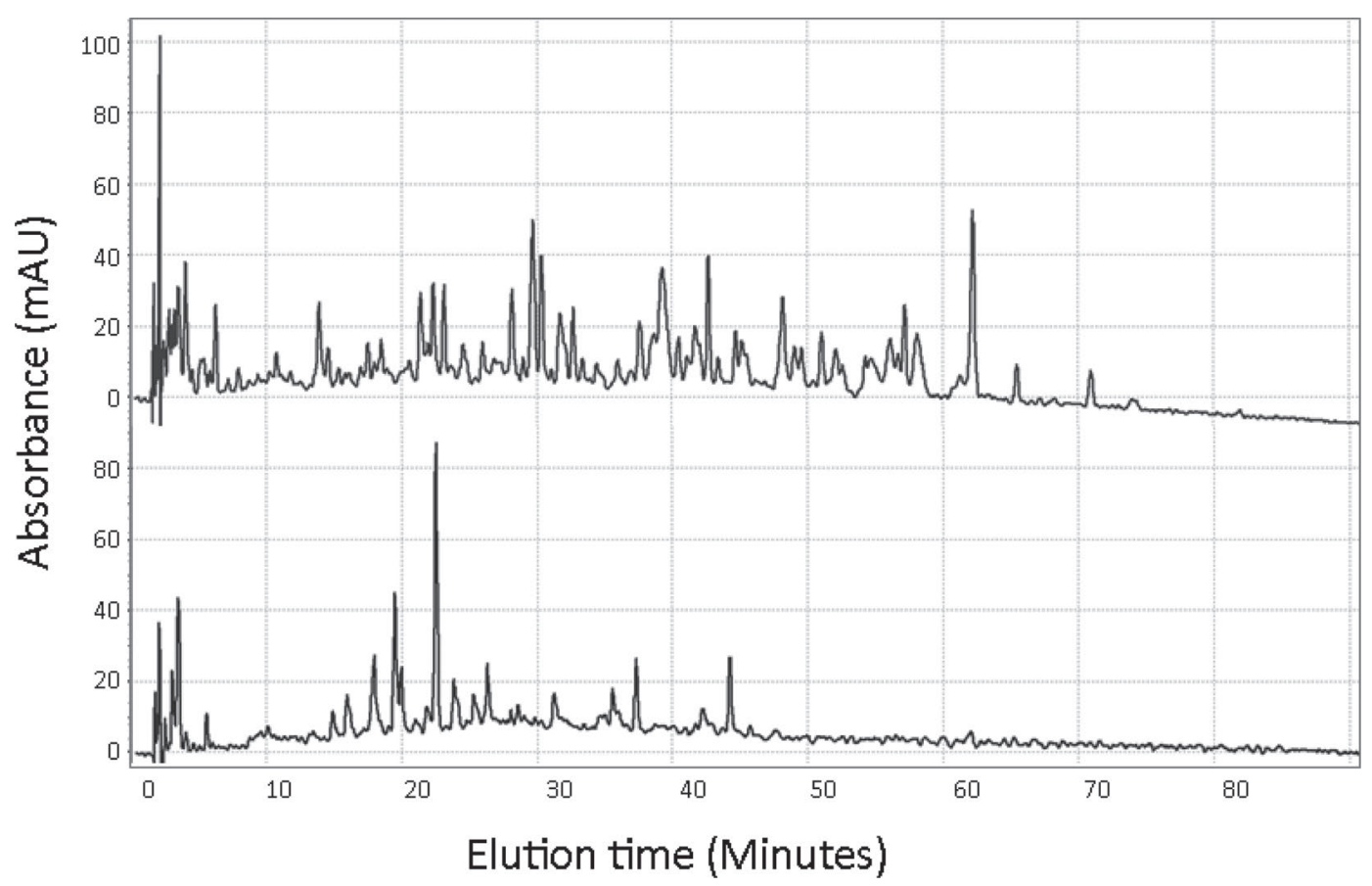

Figure 2. Chromatograms of goat caseinate (top) and goat phosphopeptide (bottom) at $214 \mathrm{~nm}$, bandwidth of $8 \mathrm{~nm}$, reference at $360 \mathrm{~nm}$ with a bandwidth of $50 \mathrm{~nm}$.

phosphorylated peptide to be precipitated by calcium and ethanol, at least 1 phosphoseryl group must be present, followed by an acidic residue, and binding may be restricted if the acidic residue is not next in sequence to the phosphoserine residue (Adamson and Reynolds, 1996). On this basis, and in the absence of mass spectrometry analysis, it is reasonable to assume that the isolated peptides contained phosphoserine residues or clusters, and that the peptides that contained no phosphoseryl groups were removed.

\section{Iron Chelation}

Typically, iron-binding measurements in milk systems use ultracentrifugation or filtration to partition species based on size to determine bound and nonbound phases (Hegenauer et al., 1979; Gaucheron et al., 1996, 1997; Raouche et al., 2009). However, because the peptides of interest are small, they may be incorrectly measured using these techniques. Therefore, we used a more direct method using ferrozine, which does not require separation of sample components. Ferrozine measures only unbound ferrous iron, so an estimation of protein chelation of iron can be obtained. Many authors, including Decker and Welch (1990), Farvin et al. (2010), and O'Loughlin et al. (2015), have used variations of this method in dairy-based systems to measure the iron-binding capacity of the protein of interest.
Effect of pH, Temperature, and Ionic Strength. As shown in Figure 3, temperature, $\mathrm{pH}$, and ionic strength were significant factors $(P<0.001)$ in the iron-binding capacity of the peptides. At $\mathrm{pH} 2.75$, almost all of the iron remained free and in the reduced form over the temperature range tested. At $4^{\circ} \mathrm{C}$, the iron remained unbound to the peptides, and at $20^{\circ} \mathrm{C}$, under ionic-strength conditions of $50 \mathrm{mM}$, the amount of iron bound to the peptides was also below the level of detection $(0.01 \pm 0.08 \mathrm{mg}$ of $\mathrm{Fe} / \mathrm{g}$ of protein). These findings indicate that iron does not bind to protein under highly acidic conditions. This may be because of protein precipitation (Taborsky, 1980), which could result in steric hindrance to the binding site, or protonation of the serine phosphate groups, which would also prevent binding (Castellani et al., 2004). The isoelectric points of the isolates were 3.67 and 3.55 for cow and goat peptides, respectively (data not shown). The peptides would be positively charged at $\mathrm{pH} 2.75$, so protonation of the side chains appears to inhibit iron binding. Interestingly, Ait-Oukhatar et al. (2000) found that lowering the $\mathrm{pH}$ to 2.5 after iron was added to $\beta-\mathrm{CN}(1-25)$ casein did not cause a release of iron because of covalent bonding; therefore, it is likely that binding the iron to the peptides before lowering the $\mathrm{pH}$ would not cause the same effect as observed in this experiment. This finding would have important implications for processing and nutrition. 
At $\mathrm{pH} 4.6$, iron binding by the peptides increased and was particularly sensitive to temperature: in a $50 \mathrm{mM}$ buffer, binding at $20^{\circ} \mathrm{C}$ was $0.64 \pm 0.06 \mathrm{mg}$ of $\mathrm{Fe} / \mathrm{g}$ of protein, increasing to $2.92 \pm 0.43 \mathrm{mg}$ of $\mathrm{Fe} / \mathrm{g}$ of protein at $37^{\circ} \mathrm{C}$ and $6.17 \pm 0.01 \mathrm{mg}$ of $\mathrm{Fe} / \mathrm{g}$ of protein at $72^{\circ} \mathrm{C}$. Increasing the ionic strength to $400 \mathrm{~m} M$ inhibited iron binding $\left(0.53 \pm 0.06 \mathrm{mg}\right.$ of $\mathrm{Fe} / \mathrm{g}$ of protein at $\left.37^{\circ} \mathrm{C}\right)$, possibly due to salting out of the protein, preventing access to the binding sites for iron. At $\mathrm{pH} 4.6$, above the isoelectric point, the peptides are slightly negatively charged; affinity between the phosphate and side-chain groups and iron cations would be greater.

At pH 6.7, the iron-binding activity was greater compared with the acidic buffers, because the proteins have more available binding sites, being further away from the isoelectric point (Castellani et al., 2004). At low ionic strength, iron binding increased in a curvilinear and likely sigmoidal fashion with temperature. We observed a significant difference in binding: for example, the binding increased from $8.87 \pm 0.02 \mathrm{mg}$ of $\mathrm{Fe} / \mathrm{g}$ of protein at $20^{\circ} \mathrm{C}$ to $10.09 \pm 0.11 \mathrm{mg}$ of $\mathrm{Fe} / \mathrm{g}$ of protein $(P$ $<0.01)$ at $72^{\circ} \mathrm{C}$. The higher ionic strength of $400 \mathrm{mM}$ resulted in decreased iron binding: at $20^{\circ} \mathrm{C}$, the binding was $4.05 \pm 0.05 \mathrm{mg} \mathrm{Fe} / \mathrm{g}$ protein, with a sharp increase in binding at $37^{\circ} \mathrm{C}$ of $7.44 \pm 0.01 \mathrm{mg}$ of $\mathrm{Fe} / \mathrm{g}$ of protein and then a more gradual increase to $72^{\circ} \mathrm{C}$. This finding may indicate that under pasteurization conditions,

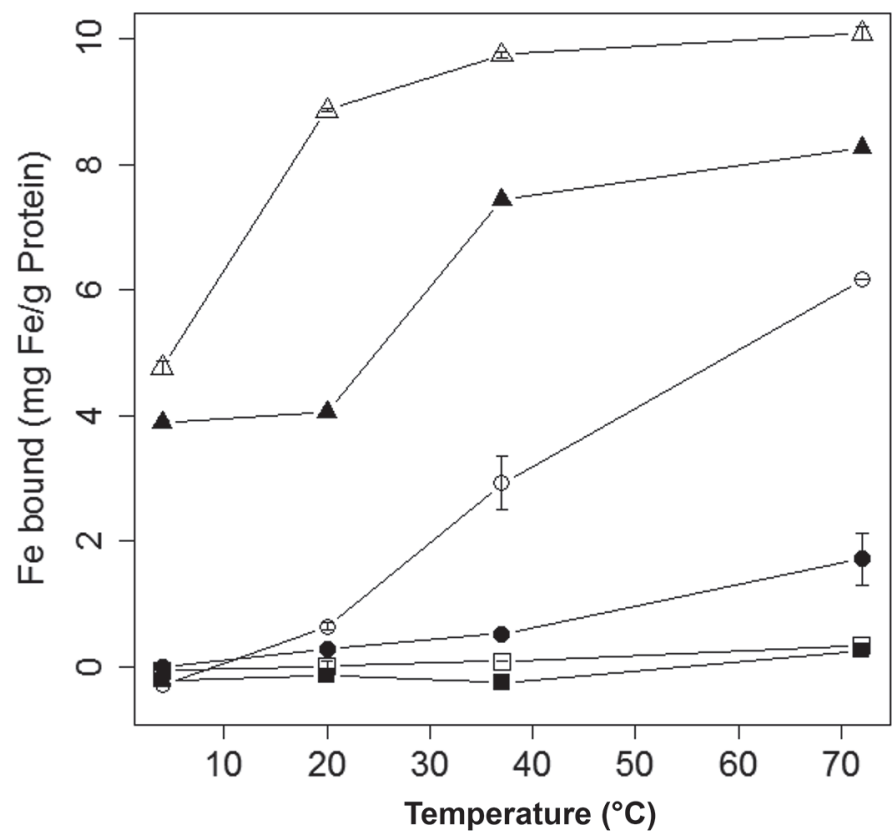

Figure 3. Iron bound by goat phosphopeptides in buffers at $\mathrm{pH}$ $2.75(\square), 4.60(\bigcirc)$, and $6.70(\Delta \mathbf{\Lambda})$ at ionic strength of $50 \mathrm{~m} M$ (open symbols) and $400 \mathrm{~m} M$ (solid symbols) after blank subtraction of iron in respective buffers. Error bars indicate SE. the binding of iron will not be significantly affected by low ionic strength, because within the duration of the experiment (3 min) we observed no dissociation of iron at $72^{\circ} \mathrm{C}$.

Over the range of parameters we studied $(\mathrm{pH} 2.75-$ 6.7 , ionic strength of the buffer 50 and $400 \mathrm{mM}$, temperature $4-72^{\circ} \mathrm{C}$ ), we measured maximum iron binding at neutral $\mathrm{pH}$ in a buffer with low ionic strength. This observation was likely due to the lower competition of salt for binding sites in an unprotonated environment. Castellani et al. (2004) looked at similar conditions using phosvitin from egg yolks and found that the optimal conditions for iron binding were at $\mathrm{pH} 6.5$ at a low ionic strength of $0.15 \mathrm{M}$. At this $\mathrm{pH}$, Castellani et al. (2004) suggested that the phosphates are completely ionized and that little salt remains to compete with iron for binding sites. Wang et al. (2011) found optimal iron-binding conditions for yak casein digests of $\mathrm{pH} 6.0$ at $40^{\circ} \mathrm{C}$. Similarly, the temperature for binding appeared to be optimal at $37^{\circ} \mathrm{C}$ or above in our study. Iron will bind to peptides in solutions that are mildly acidic and ideally low in ionic strength at temperatures above $20^{\circ} \mathrm{C}$.

Effect of Holding Time on Iron Binding. Holding stages regularly occur during manufacturing, so the point at which iron is added will determine what temperature/time profiles the iron-peptide mixture will be subjected to. It is therefore critical to understand the effect of process delays (holding time) on iron-peptide mixtures held at constant temperatures.

As shown in Figure 4a, the effect of temperature on the response of iron binding depends on the holding time $(P<0.001)$. At $20^{\circ} \mathrm{C}$, the binding of iron to the protein increased by $48 \%$ as the holding time increased with an ionic strength of $50 \mathrm{mM}$; the binding after 3 min was $13.10 \pm 0.09 \mathrm{mg}$ of $\mathrm{Fe} / \mathrm{g}$ of protein and increased to $19.46 \pm 0.01 \mathrm{mg}$ of $\mathrm{Fe} / \mathrm{g}$ of protein $(P<$ 0.001 ) after $25 \mathrm{~min}$. Likewise, the binding at $37^{\circ} \mathrm{C}$ also increased significantly from $15.38 \pm 0.32 \mathrm{mg}$ of $\mathrm{Fe} / \mathrm{g}$ of protein to $20.65 \pm 1.33 \mathrm{mg}$ of $\mathrm{Fe} / \mathrm{g}$ of protein over the same time frame $(P<0.05)$. Within this period, ferrous iron in an imidazole buffer is relatively stable, and over $80 \%$ of the added iron remains in the ferrous form (Figure $4 \mathrm{~b}$ ). At $50^{\circ} \mathrm{C}$ and $72^{\circ} \mathrm{C}$, the binding decreased with time, caused in part by the blank buffer; at these elevated temperatures, the rate of iron oxidation was greater. The confounding factor of the ferrous iron oxidizing must be taken into account. Based on the data we obtained, at $72^{\circ} \mathrm{C}$ the iron dissociated from the protein as time progressed; however, it is more likely that when free ferrous ions are in solution with no chelators, they will experience a faster rate of oxidation than when protein is present. Ruegg et al. (1977) found 

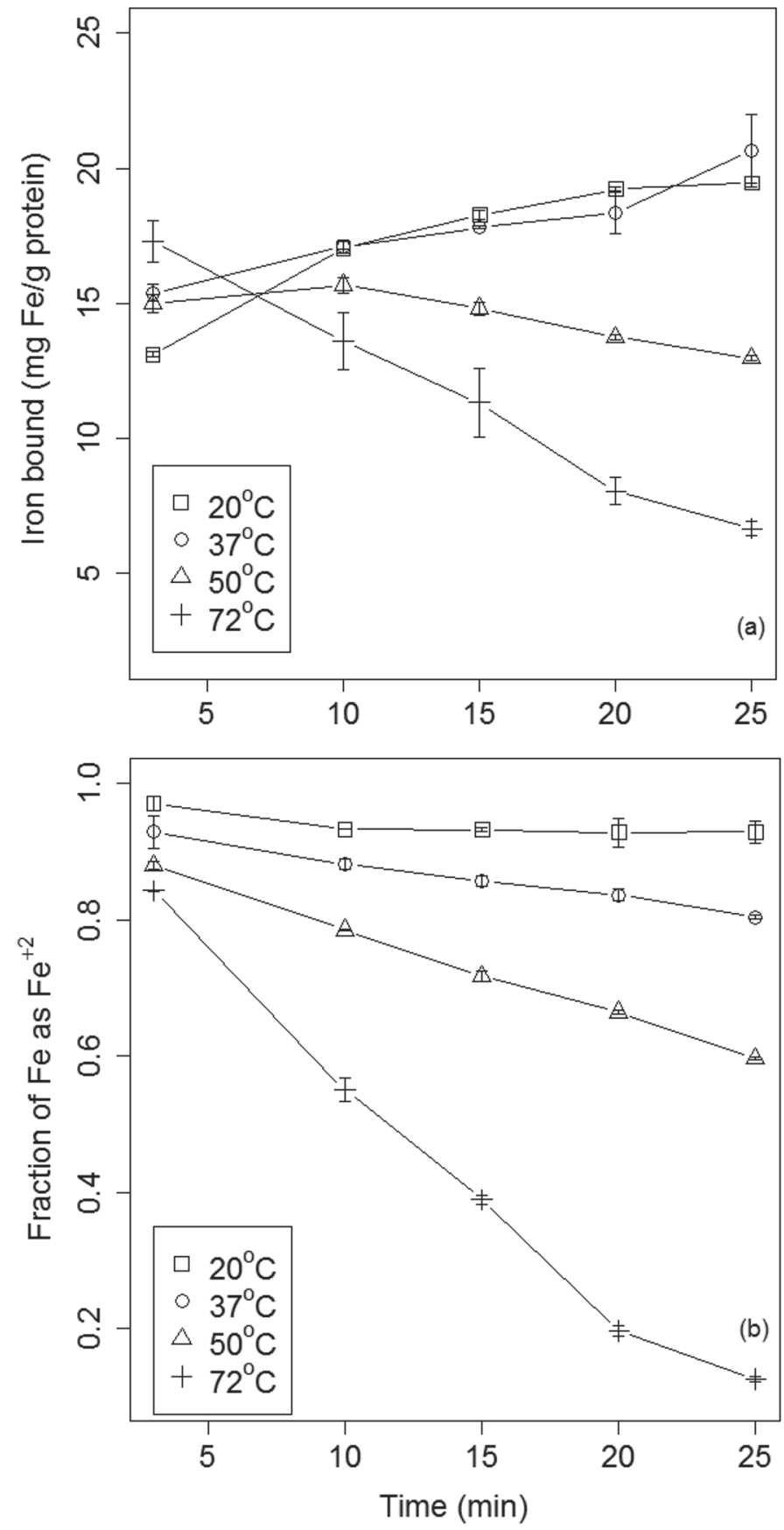

Figure 4. (a) Effect of holding time of iron and goat phosphopeptides on iron chelation capacity, with blank subtraction with respect to time; (b) background curves of ferrous iron oxidation rate as a fraction of the initial ferrous iron concentration. Error bars indicate SE.

that iron dissociated from saturated lactoferrin upon fast-rate heating, using calorimetry with a monoferric species developing in simulated milk ultrafiltrate. However, lactoferrin was a structured protein, so it would likely behave differently than a peptide. Due to the uncertainty of the oxidation and binding kinetics of iron, solutions should not be incubated at temperatures above $50^{\circ} \mathrm{C}$ because oxidation, or unbinding of ferric iron, could occur, or both.

Maximum Iron Binding of Phosphopeptides. We investigated iron loading of the peptide to determine if a saturation point could be determined. This would allow us to quantify how much iron could be added to the peptide mixture before significant amounts remained unbound and susceptible to binding to other components. The interaction of temperature and iron loading was significant for iron binding $(P<0.001)$.

At $20^{\circ} \mathrm{C}$, binding at the higher iron loadings of 100 to $265 \mu \mathrm{M}$ was significantly lower $(P<0.05)$ than at $37^{\circ} \mathrm{C}$ and $50^{\circ} \mathrm{C}$ (Figure 5). At $20^{\circ} \mathrm{C}$, iron binding increased from $10.36 \pm 0.09 \mathrm{mg}$ of $\mathrm{Fe} / \mathrm{g}$ of protein at $25 \mu \mathrm{M}$ to $42.24 \pm 0.97 \mathrm{mg}$ of $\mathrm{Fe} / \mathrm{g}$ of protein at $212 \mu \mathrm{M}$ iron. Similarly, at $37^{\circ} \mathrm{C}$, the binding at the lowest iron loading was $10.36 \pm 0.01 \mathrm{mg}$ of $\mathrm{Fe} / \mathrm{g}$ of protein, but in contrast to the findings at $20^{\circ} \mathrm{C}$, binding at the maximum loading increased to $50.16 \pm 0.63 \mathrm{mg}$ of $\mathrm{Fe} / \mathrm{g}$ of protein. At $50^{\circ} \mathrm{C}$, iron binding was initially similar to that at both 20 and $37^{\circ} \mathrm{C}(9.94 \pm 0.02 \mathrm{mg}$ of $\mathrm{Fe} / \mathrm{g}$ of protein), but at the high iron level of $212 \mu \mathrm{M}$, the binding increased further to $54.37 \pm 0.50 \mathrm{mg}$ of $\mathrm{Fe} / \mathrm{g}$ of protein. Increasing the iron concentration to $265 \mu M$ resulted in a decrease in binding, indicating that the maximum iron binding was approximately $212 \mu M$. Emery (1992)

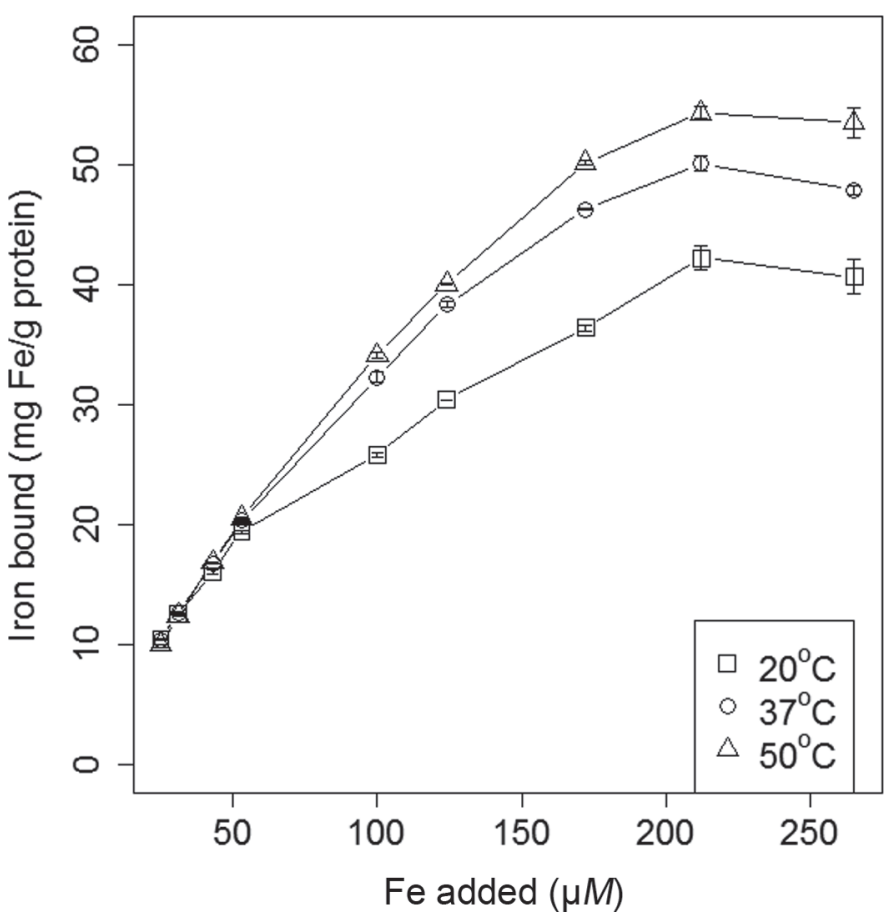

Figure 5. Effect of higher iron loading on goat phosphopeptides at $\mathrm{pH} 6.70$ and ionic strength of $50 \mathrm{mM}$. Error bars indicate SE. 
performed similar work with casein and ferrous iron and found that the iron was rapidly oxidized to $\mathrm{Fe}^{3+}$ in the presence of casein using ferrozine; the reaction can serve as a thermodynamic trap where the oxidation of iron promotes further oxidation. The rate of oxidation was highly dependent on the concentration of casein, and in our study the different iron loadings may have affected iron-binding capacity.

Gaucheron et al. (1996) found that adding iron to caseins caused precipitation at $4 \mathrm{mM}$, and Raouche et al. (2009) found that milk could bind $20 \mathrm{mmol} / \mathrm{kg}$ of milk under chilled conditions. Hekmat and McMahon (1998) added $100 \mathrm{mg} / \mathrm{L} \mathrm{FeCl}_{3}$ to milk and found that $83 \%$ remained in the casein pellet within the $\mathrm{pH}$ range of 5.3 to 6.7 and Emery (1992) estimated that casein could bind $10 \mathrm{mg} / \mathrm{g}$ of casein. Mittal et al. (2015) found that more than $90 \%$ of added iron could be bound to a calcium-depleted milk solution at $11 \%$ (wt/wt), which roughly corresponds to $26 \mathrm{mg}$ of $\mathrm{Fe} / \mathrm{g}$ of protein at $5^{\circ} \mathrm{C}$. These results show significant binding of iron using peptides compared with intact casein proteins.

The peptides in our study had significantly improved iron-binding capacity over milk and caseinate systems, but they did not match the findings of Bouhallab et al. (2002), who reported binding of $70 \mathrm{mg}$ of iron/g of phosphopeptide. These authors used ferrous chloride with a molar ratio of 4 that was bound to $\beta-\mathrm{CN}(1-25)$ at $37^{\circ} \mathrm{C}$ at $\mathrm{pH}$ 6.5. This finding indicates that using a single peptide enabled complex formations with higher binding capacities than an extracted peptide mix with no further purification. Chaud et al. (2002) bound ferric iron with a digest and found that the resultant precipitate contained $5.61 \%$ ferric chloride hexahydrate by weight, or $51.6 \mathrm{mg}$ of $\mathrm{Fe} / \mathrm{g}$ of protein, similar to the results obtained in our study.

Addition of Peptides to a Milk Model. We investigated the ability of the phosphopeptides to bind iron in a milk system to determine their effectiveness at delivering iron in a model commercial-style application. We postulated that adding the iron to a peptide solution first would, in the absence of competition from intact casein, increase the probability for iron-peptide interactions and result in more effective iron binding in the final milk system.

The fraction of peptide addition and the point at which the iron was added during manufacture significantly affected iron binding $(P<0.001)$ in the model iron-fortified milk formulation. The iron binding of goat milk without peptide addition was $3.83 \pm 0.01$ $\mathrm{mg}$ of $\mathrm{Fe} / \mathrm{g}$ of protein. At all levels of peptide addition, we observed an improvement in the amount of iron bound when the iron was added to the peptide solution first, rather than adding it directly to a peptide and milk mixture (Figure 6). This finding supports the

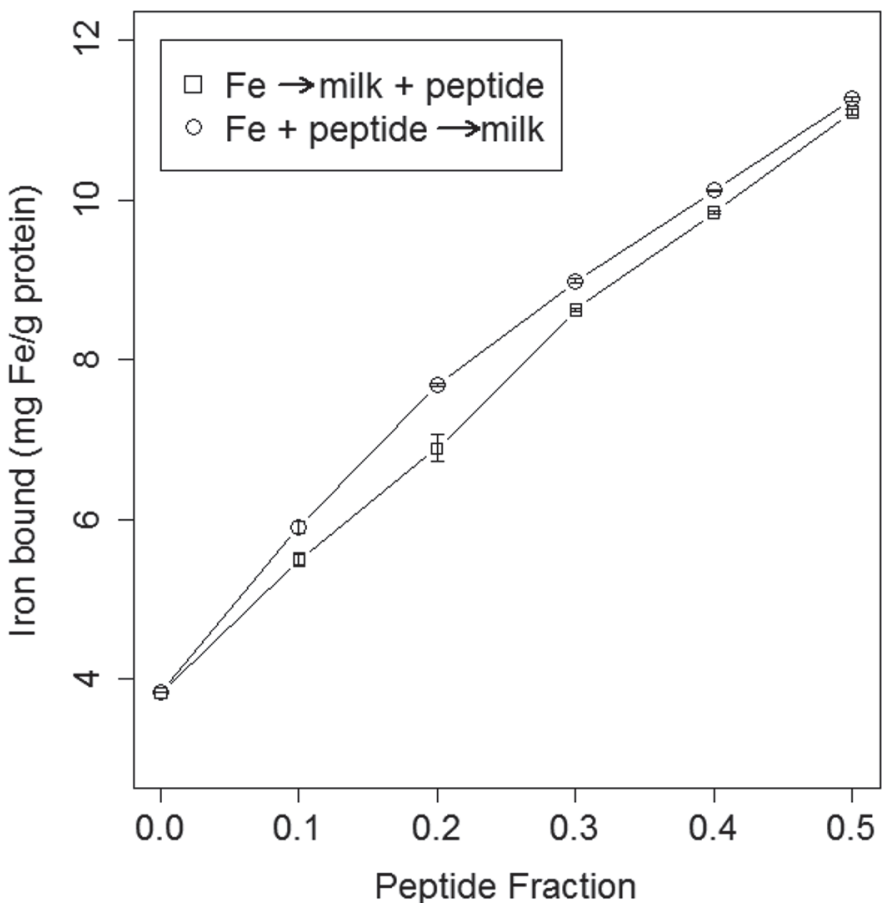

Figure 6. Iron binding by milk and peptide mixtures. Squares indicate where iron was added to a $0.2 \mathrm{mg} / \mathrm{mL}$ solution of milk protein and peptides containing $0,0.1,0.2,0.3,0.4$, and 0.5 mass fraction of peptide; circles indicate where the iron and peptide solution were first mixed and added to a milk solution with a final peptide mass fraction as before. Error bars indicate SE.

hypothesis that iron binding can be improved by adding it to a peptide stream before adding it to milk to ensure binding between these 2 ingredients and to limit interactions with other components. The percentage improvement in iron binding in the final milk solution varied with peptide concentration: at $0.1 \mathrm{~g}$ of peptide/g of total protein, improvement was $6.9 \%$ when the iron and peptide were added first and reached a maximum at $0.2 \mathrm{~g}$ peptide/g total protein at $10.3 \%$ improvement; at $0.5 \mathrm{~g}$ peptide/g total protein, we observed a $1.5 \%$ difference $(P>0.05)$. Binding of iron added to the premixed milk and peptide solution at a $50 \%$ peptide addition was $11.11 \pm 0.04 \mathrm{mg}$ of $\mathrm{Fe} / \mathrm{g}$ of protein, slightly less than when the peptide and iron were mixed first $(11.27 \pm 0.02 \mathrm{mg}$ of $\mathrm{Fe} / \mathrm{g}$ of protein). This difference was statistically significant $(P<0.05)$, but we do not believe it is nutritionally significant.

It is likely that as the peptide concentration increases, the relative importance of creating an iron-peptide solution first decreases, because the chance of an ironpeptide interaction when iron is added directly to the milk peptide solution would be higher.

A significant amount of peptide must be added into the solution before the iron binding is significantly higher than in normal milk; the food would have to 
contain about $10 \%$ as peptides of the total protein to bind $5 \mathrm{mg}$ of iron/g of protein. Statistically, the order of addition appeared to affect iron binding, but realistically these conditions would produce little difference; if a $20 \%$ mass fraction of phosphopeptide was added, a $10 \%$ increase in binding may improve the stability of the product. However it is likely that this level of addition is not commercially economical. In the context of a nutritional drink, a 250-mL serving containing $3.5 \%$ protein and a peptide fraction of 0.1 could deliver $5.25 \mathrm{mg}$ of peptide-bound iron, equating to $30 \%$ recommended daily intake for a female New Zealander aged 19 to 50 yr. However, the absolute amount of iron binding is only one of the factors that would influence the commercial success of a peptide-based iron-binding product. Also of importance is the reactivity of the bound iron: iron-fortified nutritional formulations typically contain fats that are prone to oxidizing, and the presence of free iron leads to increased oxidation rates. The effect of peptide addition on the iron-mediated oxidation of fat will be the subject of future investigation.

\section{CONCLUSIONS}

A fundamental understanding of how an iron-phosphopeptide compound would behave in an industrial setting under different processing conditions is important for determining where it could be added to the bulk mix. Isolation of the peptides improved iron binding compared with milk at the same concentration, to approximately $3.8 \mathrm{mg}$ of $\mathrm{Fe} / \mathrm{g}$ of protein. This study showed that the iron-phosphopeptide complex has potential for binding considerable amounts of iron, but it can be sensitive to temperature and holding times. We found that optimal maximum binding temperature was approximately $50^{\circ} \mathrm{C}$; the highest iron loading tested at $125 \mathrm{mg}$ of $\mathrm{Fe} / \mathrm{g}$ of protein bound $54 \mathrm{mg}$ of $\mathrm{Fe} / \mathrm{g}$ of protein. Elevated temperatures may negatively affect the rate of iron oxidation, and a lower temperature may reduce the potential oxidation of unbound iron. At temperatures below $37^{\circ} \mathrm{C}$, the iron and peptide compound can be held for up to 25 min without significant detrimental effects. The order of iron and peptide addition to a milk system had no significance in terms of industrial relevance, but even the addition of peptide at a fraction of 0.1 in a milk system improved iron binding by 27 to $33 \%$.

\section{REFERENCES}

Adamson, N. J., and E. C. Reynolds. 1995. Characterisation of tryptic casein phosphopeptides prepared under industrially relevant conditions. Biotechnol. Bioeng. 45:196-204.
Adamson, N. J., and E. C. Reynolds. 1996. Characterisation of casein phosphopeptides prepared using alcalase: Determination of enzyme specificity. Enzyme Microb. Technol. 19:202-207.

Aitt-Oukhatar, N., S. Bouhallab, P. Arhan, J. Maubois, M. Drosdowsky, and D. Bougle. 1999. Iron tissue storage and haemoglobin levels of deficient rats repleted with iron bound to the caseinophosphopeptide 1-25 of beta casein. J. Agric. Food Chem. 47:2786-2790.

Aît-Oukhatar, N., S. Bouhallab, F. Bureau, P. Arhan, J.-L. Maubois, and D. L. Bouglé. 2000. In vitro digestion of caseinophosphopeptide-iron complex. J. Dairy Res. 67:125-129.

AOAC International. 2012. Official Methods of Analysis of AOAC International. 19th ed. AOAC International, Gaithersburg, MD.

Apweiler, R., A. Bairoch, and C. H. Wu. 2004. Protein sequence databases. Curr. Opin. Chem. Biol. 8:76-80.

Bartlett, G. R. 1959. Phosphorous assay in column chromatography. J. Biol. Chem. 234:466-468.

Baumy, J. J., and G. Brule. 1988. Effect of $\mathrm{pH}$ and ionic strength on the binding of bivalent cations to $\beta$-casein. Lait $68: 409-418$.

Bouhallab, S., and D. Bouglé. 2004. Biopeptides of milk: Caseinophosphopeptides and mineral bioavailability. Reprod. Nutr. Dev. 44:493-498

Bouhallab, S., V. Cinga, N. Aît-Oukhatar, F. Bureau, D. Neuville, P. Arhan, J-L. Maubois, and D. Bouglé. 2002. Influence of various phosphopeptides of caseins on iron absorption. J. Agric. Food Chem. 50:7127-7130.

Busti, F., N. Campostrini, N. Martinelli, and D. Girelli. 2014. Iron deficiency in the elderly population, revisited in the hepcidin era. Front. Pharmacol. 5:83.

Castellani, O., C. Guerin-Dubiard, E. David-Briand, and M. Anotn 2004. Influence of physicochemical conditions and technological treatments on the iron binding capacity of egg yolk phosvitin. Food Chem. 85:569-577.

Chaud, M. V., C. Izumo, Z. Nahaal, T. Shuhama, M. Bianchi, and O. de Freitas. 2002. Iron derivatives from casein hydrolysates as a potential source in the treatment of iron deficiency. J. Agric. Food Chem. 50:871-877.

Corsetti, A., O. Massitti, F. Minervini, P. F. Fox, and M. Gobbetti. 2003. Production of caseinophosphopeptides from Na-caseinates prepared from the milk of several species by a proteinase of Lactobacillus helveticus PR4. Food Biotechnol. 17:183-192.

Decker, E. A., and B. Welch. 1990. Role of ferritin as a lipid oxidation catalyst in muscle food. J. Agric. Food Chem. 38:674-677.

Díaz, M., C. M. Dunn, D. J. McClements, and E. A. Decker. 2003. Use of caseinophosphopeptides as natural antioxidants in oil-in-water emulsions. J. Agric. Food Chem. 51:2365-2370.

Emery, T. 1992. Iron oxidation by casein. Biochem. Biophys. Res. Commun. 182:1047-1052.

Farvin, K. H. S., C. P. Baron, N. S. Nielsen, and C. Jacobsen. 2010. Antioxidant activity of yoghurt peptides: Part 1. In vitro assays and evaluation in $\omega-3$ enriched milk. Food Chem. 123:1081-1089.

Gaucheron, F., M.-H. Famelart, and Y. Le Graët. 1996. Iron-supplemented caseins: Preparation, physicochemical characterisation and stability. J. Dairy Res. 63:233-243.

Gaucheron, F., Y. Le Graët, K. Raulot, and M. Piot. 1997. Physicochemical characterisation of iron-supplemented skim milk. Int. Dairy J. 7:141-148.

Harrell, F. E., Jr. 2014. Hmisc: Harrell Miscellaneous. R package version 3.14-4. Accessed Jan. 17, 2017. http://CRAN.R-project.org/ package $=$ Hmisc.

Hegenauer, J., P. Saltman, D. Ludwig, L. Ripley, and A. Ley. 1979. Iron-supplemented cow milk. Identification and spectral properties of iron bound to casein micelles. J. Agric. Food Chem. 27:12941301.

Hekmat, S., and D. J. McMahon. 1998. Distribution of iron between caseins and whey proteins in acidified milk. Lebensm. Wiss. Technol. 31:632-638.

Højrup, P. 2004. Proteolytic peptide mapping. Pages 227-244 in HPLC of Peptides and Proteins: Methods and Protocols. M.-I. Aguilar, ed. Humana Press, New York, NY.

Kibangou, I. B., S. Bouhallab, G. Henry, F. Bureau, S. Allouche, A Blais, P. Guerin, P. Arhan, and D. Bouglé. 2005. Milk proteins and 
iron absorption: Contrasting effects of different caseinophosphopeptides. Pediatr. Res. 58:731-734.

Kim, G.-N., H.-D. Jang, and C.-I. Kim. 2007. Antioxidant capacity of caseinophosphopeptides prepared from sodium caseinate using alcalase. Food Chem. 104:1359-1365.

McClements, D. J., and E. A. Decker. 2000. Lipid oxidation in oil-inwater emulsions: impact of molecular environment on chemical reactions in heterogeneous food systems. J. Food Sci. 65:1270-1281.

McDonagh, D., and R. J. FitzGerald. 1998. Production of caseinophosphopeptides (CPPs) from sodium caseinate using a range of commercial protease preparations. Int. Dairy J. 8:39-45.

McMeekin, T. L., and D. Polis. 1949. Milk proteins. Adv. Protein Chem. 5:201-228.

Mennella, G., A. D'Alessandro, and G. Francese. 2010. HPLC analysis of amino acids, peptides, and proteins. Pages 453-469 in High Performance Liquid Chromatography in Phytochemical Analysis. M. Waksmundzka-Hajinos and J. Sherma, ed. CRC Press, Boca Raton, FL.

Miller, J. L. 2013. Iron deficiency anemia: A common and curable disease. Cold Spring Harb. Perspect. Med. 3:1-13.

Miquel, E., J. A. Gomez, A. Alegria, R. Barbera, R. Farre, and I. Recio. 2006. Identification of casein phosphopeptides in $\beta$-casein and commercial hydrolysed casein by mass spectrometry. Food Sci. Technol. Int. 12:379-384.

Mittal, V. A., A. Ellis, A. Ye, S. Das, and H. Singh. 2015. Influence of calcium depletion on iron-binding properties of milk. J. Dairy Sci. 98:2103-2113.

Nielsen, P. M., D. Petersen, and C. Dambmann. 2001. Improved method for determining food protein degree of hydrolysis. J. Food Sci. 66:642-646.

O'Loughlin, I. B., P. M. Kelly, B. A. Murray, R. J. FitzGerald, and A. Brodkorb. 2015. Molecular characterisation of whey protein hydrolysate fractions with ferrous chelating and enhanced iron solubility capabilities. J. Agric. Food Chem. 63:2708-2714.

Patterson, A. J., W. J. Brown, and D. C. K. Roberts. 2001. Dietary and supplement treatment of iron deficiency in improvements in general health and fatigue in Australian women of childbearing age. J. Am. Coll. Nutr. 20:337-342.

Pérès, J.-M., S. Bouhallab, F. Bureau, D. Neuville, J.-L. Maubois, G. Devroede, P. Arhan, and D. Bouglé. 1999. Mechanisms of absorption of caseinophosphopeptide bound iron. J. Nutr. Biochem. 10:215-222.

R Development Core Team. 2014. R: A language and environment for statistical computing. R Foundation for Statistical Computing, Vienna, Austria. Accessed Jan. 17, 2017. http://www.R-project.org/.

Raouche, S., M. Dobenesque, A. Bot, A. Lagaude, and S. Marchesseau. 2009. Casein micelles as a vehicle for iron fortification of foods. Eur. Food Res. Technol. 299:929-935.

Reynolds, E. C., P. F. Riley, and N. J. Adamson. 1994. A selective precipitation purification procedure for multiple phosphoserylcontaining peptides and methods for their identification. Anal. Biochem. 217:277-284.

Ruegg, M., U. Moor, and B. Blanc. 1977. A calorimetric study of the thermal denaturation of whey proteins in simulated milk ultrafiltrate. J. Dairy Res. 44:509-520.

Strader, M. B., D. L. Tabb, W. J. Hervey, C. Pan, and G. B. Hurst. 2006. Efficient and specific trypsin digestion of microgram to nanogram quantities of proteins in organic-aqueous solvent systems. Anal. Chem. 78:125-134.

Swaisgood, H. E. 2003. Chemistry of the caseins. Pages 233-276 in Advanced Dairy Chemistry; Part A. P. F. Fox and P. L. H. McSweeney, ed. Kluwer Academic/Plenum, New York, NY.

Taborsky, G. 1980. Iron binding by phosvitin and its conformational consequences. J. Biol. Chem. 255:2976-2984.

Wang, X., M. Li, M. Li, X. Mao, J. Zhou, and F. Ren. 2011. Preparation and characteristics of yak casein hydrolysate-iron complex. Int. J. Food Sci. Technol. 46:1705-1710.

Zhu, Y. S., and R. J. FitzGerald. 2010. Direct nanoHPLC-ESI-QTOF MS/MS analysis of tryptic caseinophosphopeptides. Food Chem. 123:753-759. 